\title{
ENGRAVED GEMS FROM ANDETRIUM IN THE ARCHAEOLOGICAL MUSEUM IN ZAGREB
}

\author{
Iva Kaić \\ Department for Archaeology \\ Faculty of Humanities and Social Studies \\ University of Zagreb \\ Ivana Lučića 3 \\ HR - 10000 Zagreb \\ ikaic@ffzg.hr
}

UDK / UDC: 069.5(497.521.2): 736.2"652"

Izvorni znanstveni rad/Original scientific paper

https://doi.org/10.52064/vamz.54.1.9

This paper analyses 11 engraved gems from Gornji Muć. They belong to the collection of Roman engraved gems in the Archaeological Museum in Zagreb and were acquired in the $19^{\text {th }}$ century by Mijo Jerko Granić, the priest of Gornji Muć. These gems were

\section{Key words:}

Andetrium, Gornji Muć, Dalmatia, engraved gems, Archaeological Museum in Zagreb

\section{Introduction}

Among its numerous Roman finds and monuments, the Archaeological Museum in Zagreb holds a collection of Roman engraved gems, which contains more than 400 items. ${ }^{2}$ The largest part of the collection was formed during the $19^{\text {th }}$ century and the early decades of the $20^{\text {th }}$ century. Despite the fact that almost all of the gems in the collection were gathered as stray finds, the majority of them have a recorded provenance. ${ }^{3}$ That allows us to examine a group of engraved gems from Gornji Muć, where ancient Andetrium, an important military site in Dalmatia, was located. found in Gornji Muć, which was the location of the Roman auxiliary fort of Andetrium, and therefore add to our knowledge of Roman gems from military sites in Croatia.
Andetrium, a hillfort of the Delmatae, was one of the last Delmataean strongholds conquered during the Great Illyrian Revolt in $6-9 A D .{ }^{4}$ The Romans built an auxiliary fort of the same name in the nearby area, and later a civilian settlement developed there as well. ${ }^{5}$ The exact positions of both the Delmataean hillfort and the Roman auxiliary fort within the Muć Valley remain uncertain. The site of Cukova Greda is a possible location of the Delmataean hillfort, while for the Roman fort and civilian settlement the locations of Ordžija and Dobreč have been proposed. ${ }^{6}$
$1 \quad$ This work has been fully supported by the Croatian Science Foundation under the project 'Understanding Roman Borders. The Case of the Eastern Adriatic (IP-2018-01-4934)'

2 Numbering more than 400 Roman engraved gems, the collection of the Archaeological Museum in Zagreb is one of the largest glyptic collections in Croatia. (For glyptics in Croatia, see Nardelli 2011a, 1, n. 4 and Nardelli 2012, $133-134$, n. 3.) The collection is only partially published, with F. Maixner (1881a; 1881b) being the first to publish the gems collected up till 1881. (He published 127 items.) In 1942, M. Šeper published a doctoral dissertation on the magical gems of the former Yugoslavia, which included four magical gemstones from the collection in the Archaeological Museum in Zagreb (Šeper 1942, 12, 14-15, cat. nos 7-8, 15-16). In 1958, I. Degmedžić published four gemstones from Sisak engraved with zodiac signs (Degmedžić 1958). After that, the gems were only published occasionally, mainly as part of several variously themed ex- hibitions (Rendić-Miočević 1987; Larese, Nardelli (eds.) 1991; Nemeth-Ehrlich 1993a; Nemeth-Ehrlich 1993b). Some 477 gems from the collection have been analysed in an unpublished PhD thesis (Kaić 2013), with several items pub lished afterwards (Kaić 2015; 2017; 2020; 2021). For a detailed account of the publications on engraved gems from the Archaeological Museum in Zagreb, see Kaić 2017, 479, no. 1

They were found at various sites in Croatia, Serbia and Bosnia and Herzegovina that once lay in the Roman provinces of Upper and Lower Pannonia Dalmatia and Upper Moesia. Of only 18 percent of the engraved gems in the collection, the finding site is not known (Kaić 2013, 69-73).

4 Bekić 2011, 315; Cesarik 2018, 54.

5 Bekić 2011, 315

6 Bekić 2011. 
Finds of Roman epigraphic inscriptions and military stamps reveal the names of the auxiliary troops which were stationed in Andetrium up into the $3^{\text {rd }}$ century AD (cohors VIII Voluntariorum civium Romanorum, cohors III Alpinorum equitata and cohors I Belgarum) ${ }^{7}$

After the departure of the auxiliary troops during the $3^{\text {rd }}$ century $A D$, the civilian settlement acquired the character of a Late Antique castrum. ${ }^{8}$ Finds of military equipment dated to the $4^{\text {th }}$ and $5^{\text {th }}$ centuries $A D$, as well as coins of the Byzantine emperor Justin, show that the castrum existed until the middle of the $6^{\text {th }}$ century AD or the beginning of the $7^{\text {th }}$ century AD. ${ }^{9}$

\section{History of the Andetrian gems in the collection}

It is worth noting that, within this collection, among all the engraved gems from Dalmatia with a known findspot, the gems from Gornji Muć (10 engraved gems, 6 glass gems and one glass cameo) are second in number, exceeded only by the engraved gems from Salona (about 40 items)..$^{10}$ To this number we should also add a cornelian found at Ordžija, near Gornji Muć.

All the gems were obtained by the local parish priest, Mijo Jerko Granić, an amateur archaeologist, who handed them to the Archaeological Museum in Zagreb. ${ }^{11}$ He was a friend and associate of Šime Ljubić, then director of the Archaeological Museum in Zagreb. ${ }^{12}$ It was this very priest, Granić, who discovered one of the most important of Croatian archaeological monuments: an architrave with the name of the Croatian duke Branimir and the year $888 .{ }^{13}$ In the course of further construction activities on the site of the parish church of St Peter in Gornji Muć, Mijo Jerko Granić conducted amateur archaeological excavations as well, which yielded numerous Roman finds. ${ }^{14}$

From 1872 until 1886, Mijo Jerko Granić maintained a lively correspondence with Šime Ljubić, regularly informing him of his archaeological endeavours in Gornji Muć. ${ }^{15}$ In several letters the priest described how he found carved "pebbles", as he affectionately called the engraved gems. In a letter, dated $12^{\text {th }}$ May 1873, Granić mentioned three pebbles (one of which had an inscription GRE/GORI/VIVAS) he had found during the excavations of Saint Peter's Church in Gornji Muć. ${ }^{16}$ From the preserved list of donations to the Archaeological Museum in Zagreb, compiled by Šime Ljubić in the period of 1868 to 1875 ,

\footnotetext{
$7 \quad Z$ Zaninović 1996, 287, 289; Bekić 2011, 317; Matijević 2011, 184; Tončinić Tabak, Librenjak 2011, 364

8 Bekić 2011, 318.

9 Bekić 2011, 318.

10 Of the 138 pieces from Dalmatia in the collection, the exact findspot was recorded for 89 (Kaić 2013).

11 See Luetić 2001, 240.

12 For the priest M. J. Granić and his relations with the Archaeological Museum in Zagreb, see Mirnik 2010

13 Mirnik 2010

14 Kaić 2017, 482, n. 14

15 Mirnik 2010

16 Mirnik 2010,69.
}

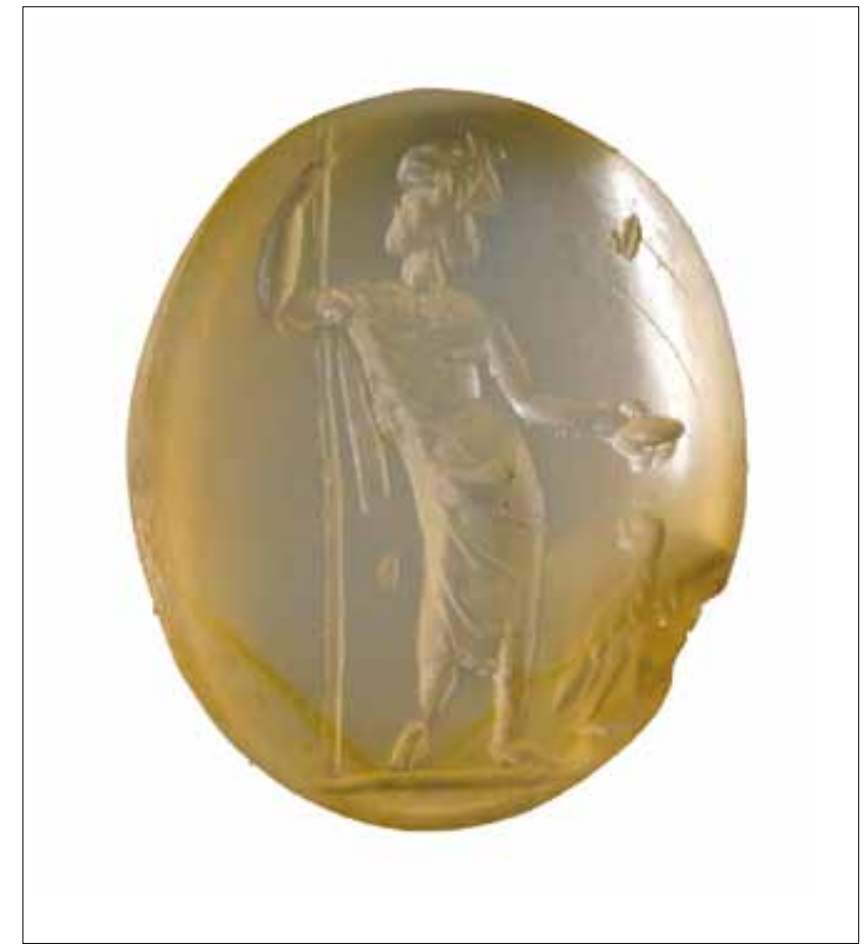

FIGURE 1. Jupiter, a chalcedony, inv. no. A-16002 (photo by I. Krajcar).

we learn that Mijo Jerko Granić gave several pebbles to the Museum in $1873 .{ }^{17}$ Among them, 8 engraved gems were listed as follows: two were without engravings, two were partially broken, but one among them carried a depiction of Victoria with a wreath, one gemstone engraved with a cornucopia, the abovementioned gemstone with an inscription, a gemstone showing an armed figure (perhaps Mars?) and a gemstone from Ordžija, depicting "Theseus" and Medusa. ${ }^{18}$

In a letter dated $29^{\text {th }}$ May 1879 , Mijo Jerko Granić describes a little pebble carved with an inscription (ARMC/A PALM/PANVM/ ELIA/PTOL M) and the figure of Apollo with a lyre. ${ }^{19}$ In a letter dated $12^{\text {th }}$ June 1885 , the priest mentions one pebble which was carved as intaglio, without precisely describing the motif; then, in another letter of $29^{\text {th }}$ January 1886 , he mentions several broken gemstones engraved with mythological scenes, and another one with a hippocamp. ${ }^{20}$ In a letter dated $26^{\text {th }}$ May 1886 , he describes a partially broken gem engraved with the image of Apollo. ${ }^{21}$

\footnotetext{
See Luetić 2001

Luetić 2001, 240

Ljubić 1879, 123-124; Mirnik 2010, 75, n. 23-24

Mirnik 2001, 81, 84

Mirnik 2001, 86.
} 
Some of the gems described in these letters are nowadays missing from the glyptic collection of the Archaeological Museum in Zagreb. ${ }^{22}$ At the same time, it is difficult to recognize all of them due to their very general descriptions in the letters. It is also not possible to discern the glass gems among them, because in his letters Mijo Jerko Granić referred only to "pebbles". Nevertheless, seven glass gems and one glass cameo within the collection testify that some of the priest's "pebbles" must have been made of glass.

In this paper we shall examine only the engraved gemstones, while the glass gems and a glass cameo from Andetrium will be discussed in a paper that will follow.

\section{Iconographic repertoire and the datation of the Andetrian engraved gems}

As we can see, the gems from Gornji Muć mostly come from the amateur archaeological excavations undertaken by Mijo Jerko Granic in the second half of the $19^{\text {th }}$ century and conducted in a manner characteristic of that time. Therefore, in datation of the Andetrian gems we must rely on their iconographic, stylistic and technical features in order to determine the period in which they were manufactured.

The engraved gems found at Gornji Muć display motifs that were part of the standard repertoire in Roman glyptic art, with depictions of Graeco-Roman deities, mythological heroes, animals, symbols and inscriptions.

Considering their material, of the nine intaglios, four were made in carnelian, two in chalcedony, and single ones in amethyst, chrome chalcedony, red jasper and nicolo.

We shall start with the depiction of Jupiter, the supreme deity of the Roman pantheon. The chalcedony (Fig. 1) ${ }^{23}$ is engraved with Jupiter standing frontally, his head turned right, his hips covered with a himation, holding a phiale in his extended left arm and leaning on a sceptre in his raised right hand. At his feet to right, an eagle is standing, with head turned left, and with its wings gathered. This iconographic type of standing Jupiter was derived from Lysippos's bronze statues of Zeus. ${ }^{24}$ Our chalcedony is worked with several drills of varying widths, and, although the face is stylised, the rendering of the figure is fluid, and classicising. Iconographic and stylistic analogies with our intaglio can be traced to a chalcedony from Gadara ${ }^{25}$ and an agate $^{26}$ from the Hague collection, as well as another unprovenanced chalcedony ${ }^{27}$ from the Zagreb collection, thus placing the Andetrium chalcedony in the period from the $1^{\text {st }}$ century AD

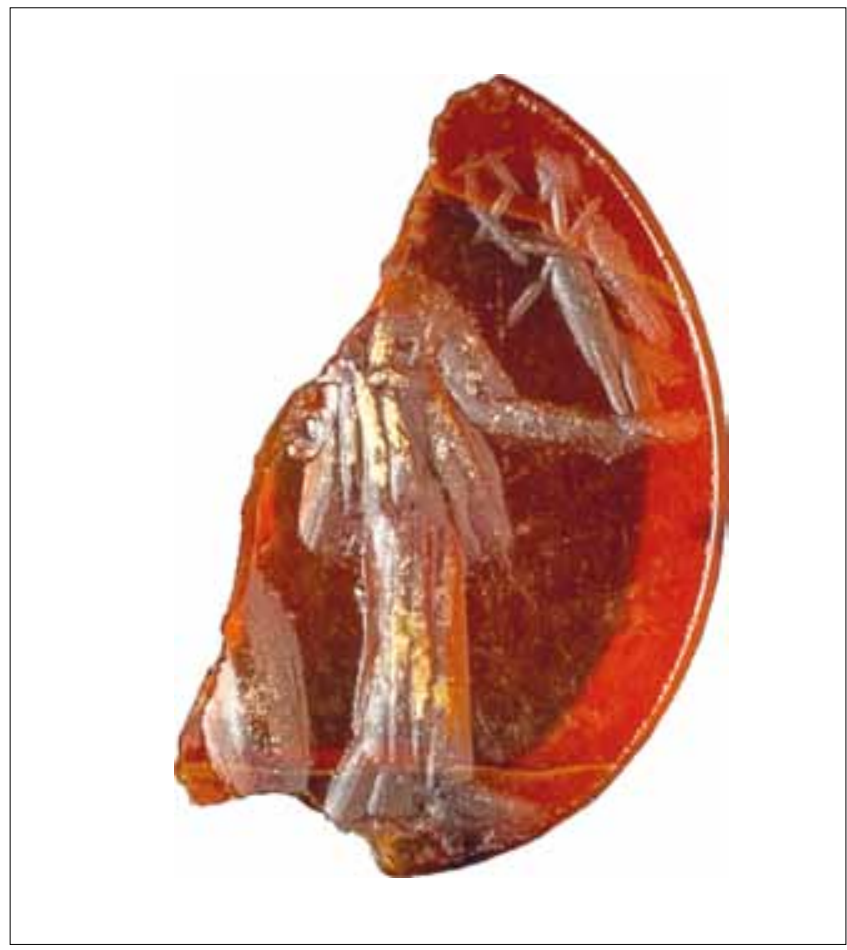

FIGURE 2. Minerva, a red cornelian, inv. no. A-16065 (photo by I. Krajcar).

to the $1^{\text {st }}$ half of the $2^{\text {nd }}$ century AD. The choice of chalcedony was not accidental, because this greyish precious stone was reminiscent of the sky's colour, which made it particularly suitable for depicting the god Jupiter. ${ }^{28}$

The third deity in the Capitoline triad, the goddess Minerva, appears on a chipped red cornelian (Fig. 2) ${ }^{29}$ which was found at the parish church in Gornji Muć. It was engraved with Minerva standing to the front with her head facing right, clad in a long peplos and holding Victoria in her extended left hand. To the left of the goddess there is a shield on the ground. It is not possible to determine the position of Minerva's right hand, due to the breakage of the stone, but she was probably holding a spear, her usual attribute. The figure is engraved accurately but schematically, with mainly broad drills, dating the cornelian to the $2^{\text {nd }}$ century AD. Stylistic and technical analogies can be found with one cornelian ${ }^{30}$ from the Kunsthistorisches Museum in Vienna, and with another one ${ }^{31}$ from the Numismatic Cabinet of the Romanian Academy Library, allowing us to date our cornelian to the $2^{\text {nd }}$ century AD.

\footnotetext{
22 For instance, the gemstone engraved with both Apollo and the inscription, as well as another Apollo gem, are only known to us from the letters.

23 Inv. no. A-16002; shape $1 ; 13.6 \times 11.39 \times 4.65$ mm. Purchased from M. J. Granić. Unpublished. Shapes of all intaglios published herein are based on AGWien 1, 15, Fig. C and Mandrioli Bizzarri 1987, 30, PI. 2.

24 Henig $2007^{3}, 28$

25 Henig, Whiting 1987, 8, cat. no. 19

26 Maaskant-Kleibrink 1978, 303, cat. no. 880, PI. 145

27 Kaić 2013, cat. no. 7.
}

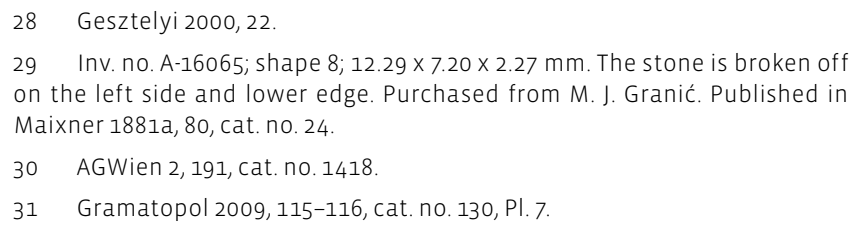




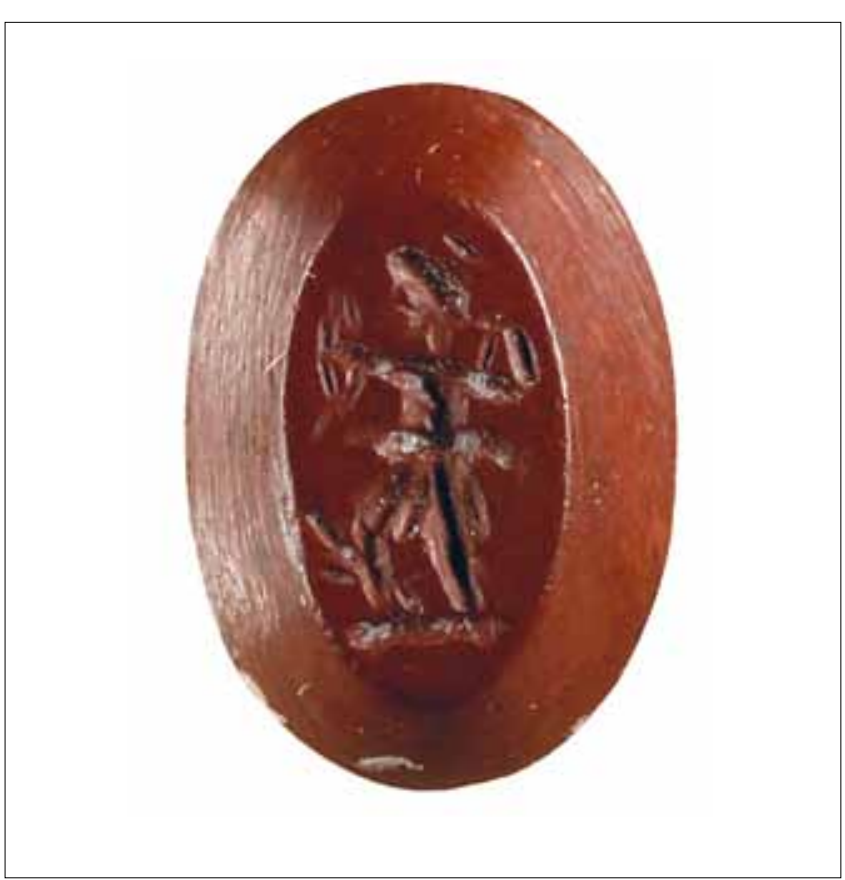

FIGURE 3. Diana Venatrix, a red jasper, inv. no. A-16246 (photo by I. Krajcar).

The goddess Diana is the subject of the red jasper (Fig. 3), ${ }^{32}$ engraved with the goddess dressed in a short chiton, running to the left. With her left hand Diana is pulling an arrow from the quiver on her back, while holding a bow in her right hand. Her hound is running by her feet. This Diana the Huntress iconographic type, derived from the sculptural prototypes, was well represented on Roman gems. ${ }^{33}$ The red jasper is rather coarsely cut with a drill at a small scale, dating our item to the $2^{\text {nd }}$ or $3^{\text {rd }}$ century. In terms of iconography and style, our red jasper can be paralleled with a green jasper ${ }^{34}$ from the Verona collection, dated to the $2^{\text {nd }}$ century AD. We can also mention a cornelian ${ }^{35}$ from Carnuntum, as well as a chalcedony ${ }^{36}$ from the Hannover collection, although that chalcedony shows certain iconographic differences (as the goddess is holding the bow in both hands, and there is no dog accompanying her).

Roman gems depicting mythological heroes have frequently been found at Roman military sites. ${ }^{37} \mathrm{~A}$ cornelian (Fig. 4 ) $^{38}$ from Ordžija, near Gornji Muć, is engraved with Perseus standing frontally with his head in profile to the right. ${ }^{39} \mathrm{He}$ is nude apart

32 Inv. no. A-16246; red jasper; shape 9; $10.74 \times 7.46 \times 2.32 \mathrm{~mm}$; purchased from M. J. Granić.

33 Magni 2009, 40, n. 66

34 Magni 2009, 41, cat. no. 44, PI. 4.

35 Dembski 2005,64, cat. no. 104, PI. 11. Dated to the $1^{\text {st }}$ or $2^{\text {nd }}$ century AD.

36 AGDS 4 Hannover, 260, cat. no. 1394, PI. 189. Dated to the $2^{\text {nd }}$ century AD.

37 Henig 1970; Henig $2007^{3}, 51$.

38 Inv. no. A-16123; shape 8; $13.5 \times 11 \times 2$ mm; purchased from M. J. Granić. Published in Maixner 1881a, 77, cat. no. 6.

39 The find site was originally written as "Orgija”, and the intaglio was described as depicting Theseus (Luetić 2001, 240; Mirnik 2010, 69, n. 21)

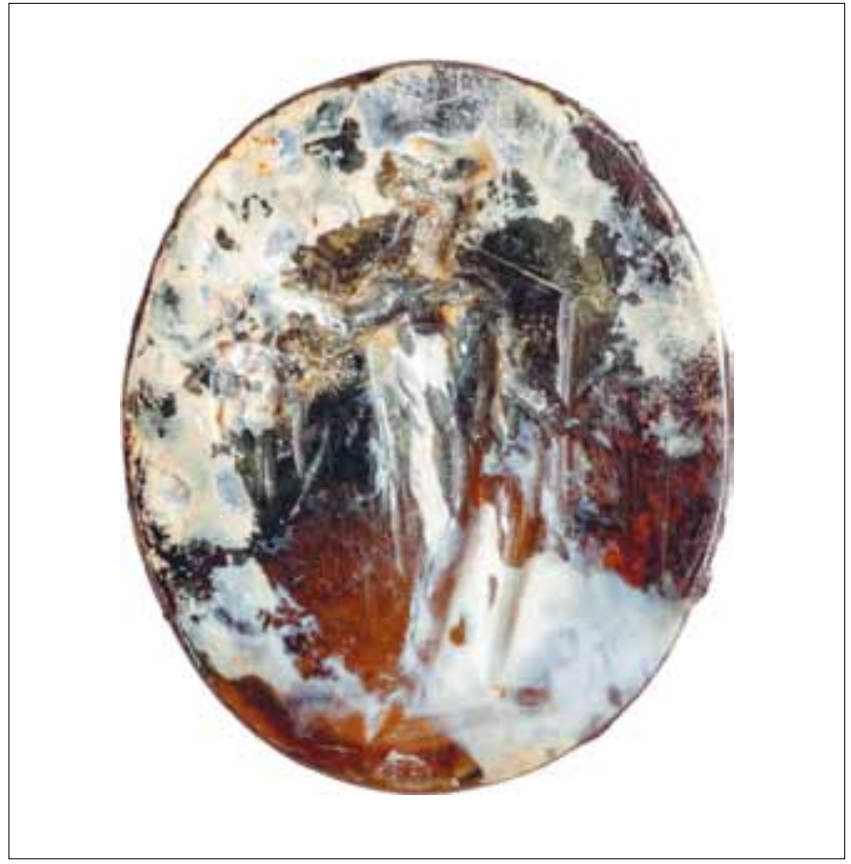

FIGURE 4. Perseus, a carnelian, inv. no. A-16123 (photo by I. Krajcar).

from the chlamys hanging from his shoulders. In his extended left hand he is holding a sword pointed upwards, while in his raised right hand he is holding the severed head of Medusa. We can compare our cornelian with a cornelian ${ }^{40}$ from Aquileia, showing Perseus holding Medusa's head with arm bent at the elbow above his head. We can also mention a yellow glass gem ${ }^{41}$ from the Munich collections, depicting Perseus with his head turned towards Medusa. The stylistic rendering of our cornelian, cut in a classicising style, places it in the $1^{\text {st }}$ century AD.

On the chrome chalcedony (Fig. 5), ${ }^{42}$ a nude figure standing in three-quarter profile with head in profile to the left is depicted. This intaglio is particularly interesting, because it represents an unfinished work. The body is schematically cut with missing details, such as the figure's feet. Yet, in the body's posture, with hips pushed forward and lowered head to the chest, perhaps we can discern the figure of Omphale or even Methe, the personification of drunkenness. The convex shape of the stone and the material of the gemstone point to the group of so-called 'Kleine Praser', the chrome chalcedonies of convex or bi-convex shape, often engraved with classical motifs ranging from the famous cult statues to sacro-idyllic scenes. ${ }^{43}$ They were mainly manufactured throughout the $1^{\text {st }}$ century $A D$, although some pieces are dated to the end of the $1^{\text {st }}$ century $B C$ or the early $2^{\text {nd }}$ century AD. ${ }^{44}$ Chrome-chalcedony gems are assigned to workshops

\footnotetext{
40 Sena Chiesa 1966, 273, cat. no. 726, PI. 37

41 AGDS I/2, 135, cat. no. 1415, PI. 140.

42 Inv. no. A-15930; shape $1 ; 8.0 \times 6.0 \times 2.5 \mathrm{~mm}$. Chipped on edges, poorly preserved surface. Purchased from M. J. Granić.

43 Platz-Horster 2010

44 Platz-Horster 2010, 191.
} 


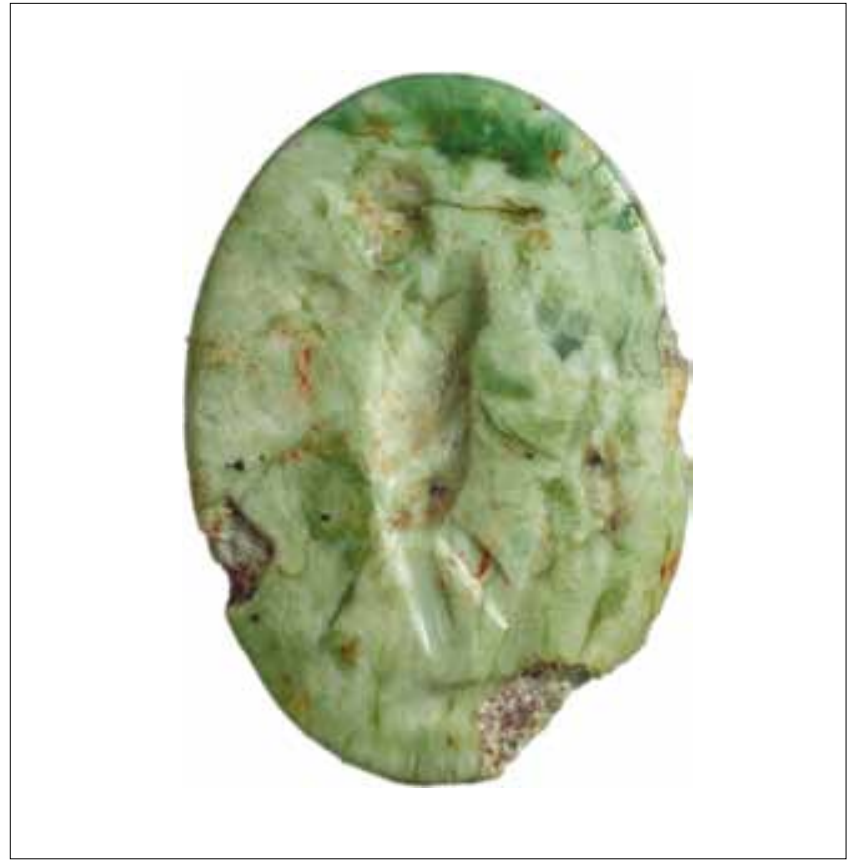

FIGURE 5. Standing figure, a green chrome chalcedony, inv. no. A-15930 (photo by I. Krajcar).

in central Italy, with the raw material supplied from a mine in central Anatolia. ${ }^{45}$ Our unfinished item points to the possibility of its having been manufactured in a local workshop, which on the other hand poses a question of whether such a workshop could have existed in Andetrium. The problem of localizing the provincial workshops, or workshops outside the major centres, is still not resolved..$^{46}$ Yet there are indications of local production of engraved gems in the Roman province of Dalmatia. A group of white chalcedonies from the Zadar area, all depicting Tyche-Fortuna, could appertain to a local glyptic workshop in Liburnia. ${ }^{47}$ Furthermore, several cornelians from Gardun depicting satyrs can be assigned to a local workshop, perhaps connected with the legionary fortress of Tilurium.$^{48} \mathrm{Although}$ it is difficult to prove a local glyptic workshop based on only one unfinished item, the Andetrian chrome chalcedony could prove important in our understanding of local production of gems within the group of convex chrome chalcedonies.

Animals appear rather frequently on Roman gems, often connected with certain gods, or as symbols of fertility and prosperity. ${ }^{49}$ On an orange cornelian (Fig. 6) ${ }^{50}$ from Gornji Muć we find a depiction of a panther, an animal associated with the god Dionysus. The carnelian is engraved with a panther either walking

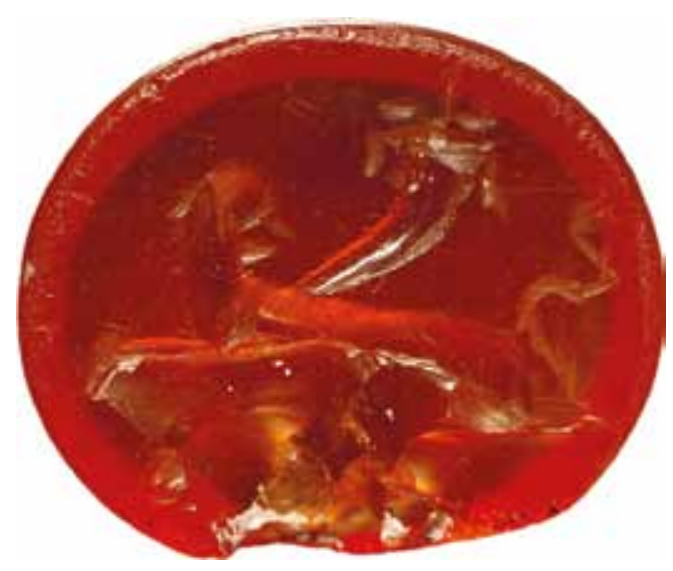

FIGURE 6. Panther with cornucopia, an orange carnelian, inv. no. A-16109 (photo by I. Krajcar).

or lying down with its body in profile to the left and its head turned backwards, with open maw. There is a cornucopia behind the panther's back. Since the top surface on the bottom half of the gemstone is damaged, it is impossible to determine the exact position of the animal's paws. The panther is convincingly executed, mainly with broad drills for the creature's body and the cornucopia, but a narrower drill for the panther's tail. Parallels in both the iconography and the style can be found with a cornelian ${ }^{51}$ from Aquileia. We can also mention a cornelian ${ }^{52}$ from Bath, showing a panther with a cornucopia placed on top of a column behind the animal. Based on these analogies, our cornelian can be dated to the $1^{\text {st }}$ or $2^{\text {nd }}$ century AD.

The habit of horse racing is reflected in an amethyst (Fig. 7), ${ }^{53}$ engraved with a victorious racehorse standing in profile to the left, with right foreleg raised. A green jasper ${ }^{54}$ from Aquileia and a cornelian 55 from the Kunsthistorisches Museum in Vienna can be cited as parallels for our motif. Short parallel lines, incised for the horse's mane, can be compared with an intaglio ${ }^{56}$ from the Arthur Evans collection. The horse is accurately cut with rounded drills for the body and narrow drills for the mane. The stylistic rendition of our amethyst places it in the $1^{\text {st }}$ century AD.

\footnotetext{
45 Platz-Horster 2010, 196.

46 Zwierlein-Diehl 2007, 145

47 Nardelli 2005

48 Nardelli 2011a, 25, nos 40-42; Nardelli 2011b, 300-302

49 Henig $2007^{3}, 54$

50 Inv. no. A-16109; shape 8; $8.98 \times 10.97 \times 2.35 \mathrm{~mm}$. Top surface on the bot tom half of the intaglio is broken off. Donated by M. J. Granić. Published in
} Maixner 1881b, 113, cat. no. 63.

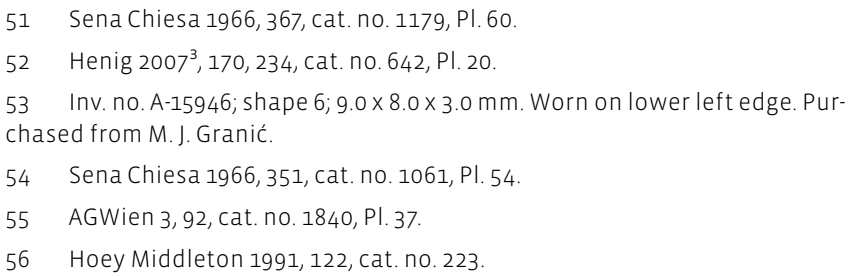




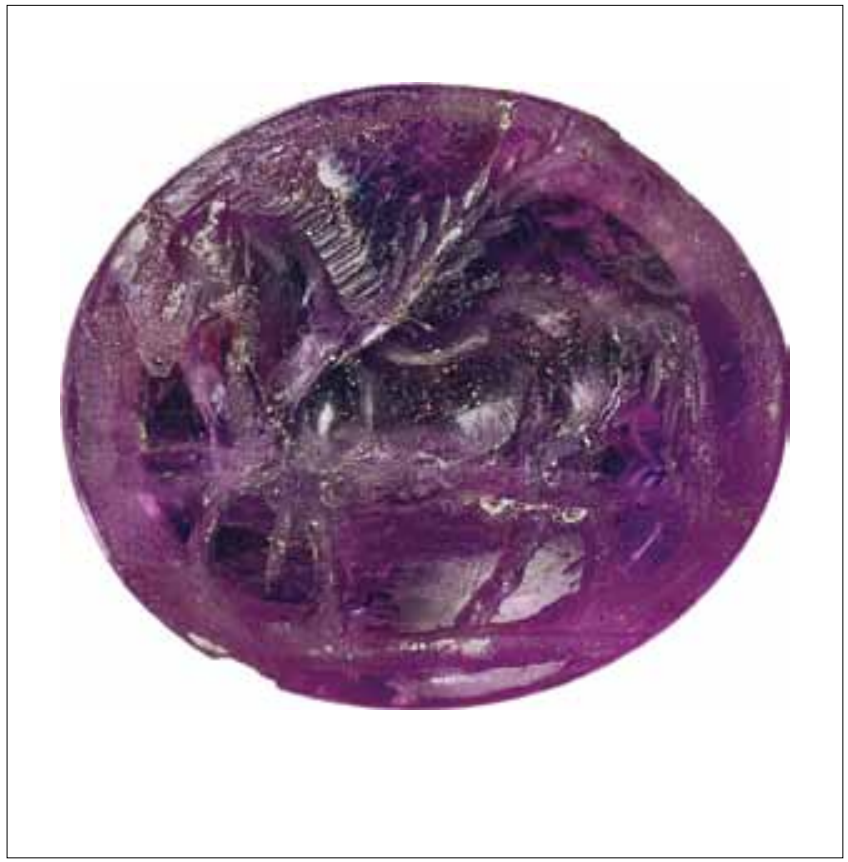

FIGURE 7. Horse, an amethyst, inv. no. A-15946 (photo by I. Krajcar).

Eagles, associated with the god Jupiter, were employed as symbols of the Roman army. On the preserved piece of a red cornelian (Fig. 8) (57 $^{5}$ an eagle is engraved as standing on a sacrificial altar, flanked by one legion signum each to the left and right of the altar. Due to the breakage of the upper two-thirds of the intaglio, only the lower part of the right wing, the tail and legs of the eagle together with lower parts of the signa have been preserved. Analogies for both the motif and the style can be found in a carnelian ${ }^{58}$ from Carnuntum and a brown jasper ${ }^{59}$ from Dalmatia. The engraving of the Andetrian carnelian is somewhat discordantly executed, dating it to the $2^{\text {nd }}$ or $3^{\text {rd }}$ century AD.

A similar motif is found on another carnelian (Fig. 9) ${ }^{60}$ in our collection, engraved with a legionary signum and an eagle. The gemstone is heavily damaged on the left side, leaving recognizable only the right wing of an eagle. It is cut schematically, with broad grooves, dating it to the $2^{\text {nd }}$ century AD. For both our cornelians we can find direct parallels with three cornelians ${ }^{61}$ from Britain, engraved with an eagle standing between the signa.

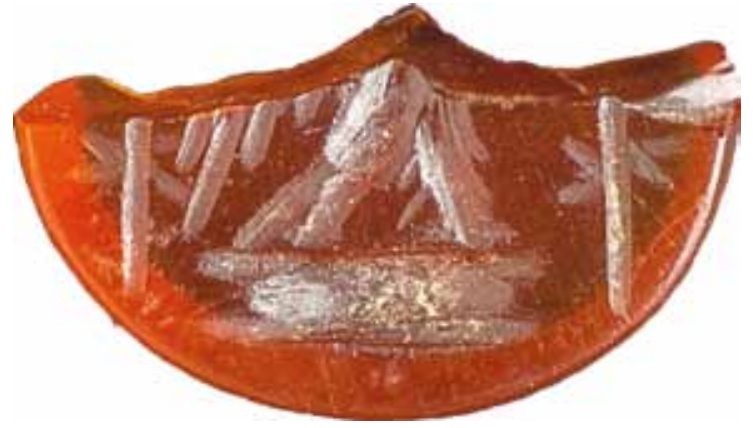

FIGURE 8. Eagle between two legion signa, a red cornelian, inv. no. A-16066 (photo by I. Krajcar).

A chalcedony (Fig. 10), ${ }^{62}$ engraved with an ear of corn between two conjoined cornucopiae, can be placed in the group of gems with a combination of symbols. In terms of iconography and style, our intaglio can be compared with a cornelian ${ }^{63}$ from the Nürnberg collection and consequently dated to the $1^{\text {st }}$ century $A D$. Bearing symbols of prosperity and abundance associated with the goddesses Ceres and Fortuna, this chalcedony was chosen to bring wealth and good fortune to its owner.

Last in the collection is a nicolo with a Latin inscription in positive (Fig. 11), that reads GRE/GORI/VIVAS ("May you live and be wakeful"). ${ }^{64}$ This nicolo was one of the three pebbles which Mijo Jerko Granić found along with the Emperor Gratian's coin, while excavating at the position of St Peter's Church in Gornji Muć in $1873 .{ }^{65}$ The closest parallel is found with a cameo portrait from Geneva, which bears the inscription A(ח)A (G)REGORI VIVAS. ${ }^{6}$ One should also mention two cameos from the Content collection with a Greek inscription that reads ГРНГОРI. ${ }^{67}$ Concerning these analogies and the Christian meaning of the inscription,
57 Inv. no. A-16066; shape 8; $6.29 \times 10.84 \times 2.03 \mathrm{~mm}$. Severely damaged: the upper two-thirds of the intaglio are broken off. It was donated by M. J. Granić. Found at the parish church in Gornji Muć (Andetrium).

58 Dembski 2005, 140, cat. no. 884, PI. 90.

59 Nardelli 2007, 271-272, cat. no. 14.

60 Inv. no. A-16067; shape $12 ; 9.83 \times 9.24 \times 3.42 \mathrm{~mm}$. Left half of the intaglio is broken off. Donated by M. J. Granić.

61 Henig $2007^{3}, 177,236$, cat. nos $707-708$, PI. 22, both dated to the $1^{\text {st }}$ century AD; 211, 245, App. 186, Pl. 31, dated to the $2^{\text {nd }}$ century AD.
62 Inv. no. A-16317; shape $11 ; 10.31 \times 11.96 \times 2.66 \mathrm{~mm}$. Purchased from M. J. Granić.

63 AGNürnberg, 155, cat. no. 435, PI. 59.

64 CIL 03: 10188, 17. For a detailed account of this intaglio and its inscription, see Kaić 2017, 482-483

65 Mirnik 2010,69.

66 Vollenweider 1979, 261-263, cat. no. 272 bis; Aubry 2011, 241, n. 36

67 Henig 1990, XIII, 26-27, cat. nos 47-48. 


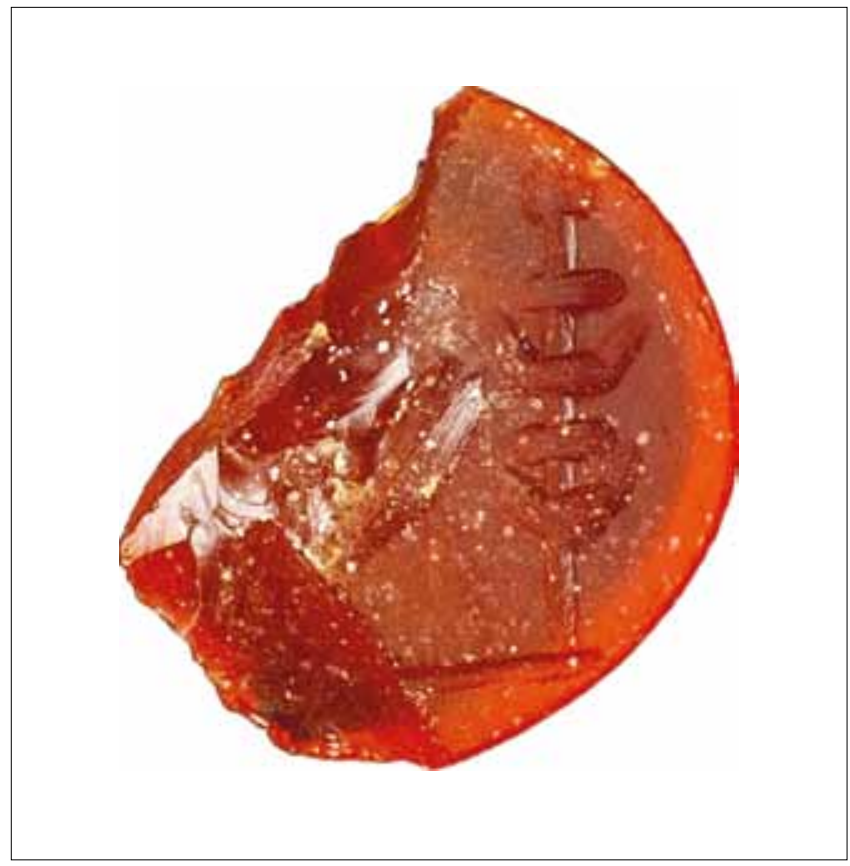

FIGURE 9. Legionary signum and eagle, a red cornelian, inv. no. A-16067 (photo by I. Krajcar).

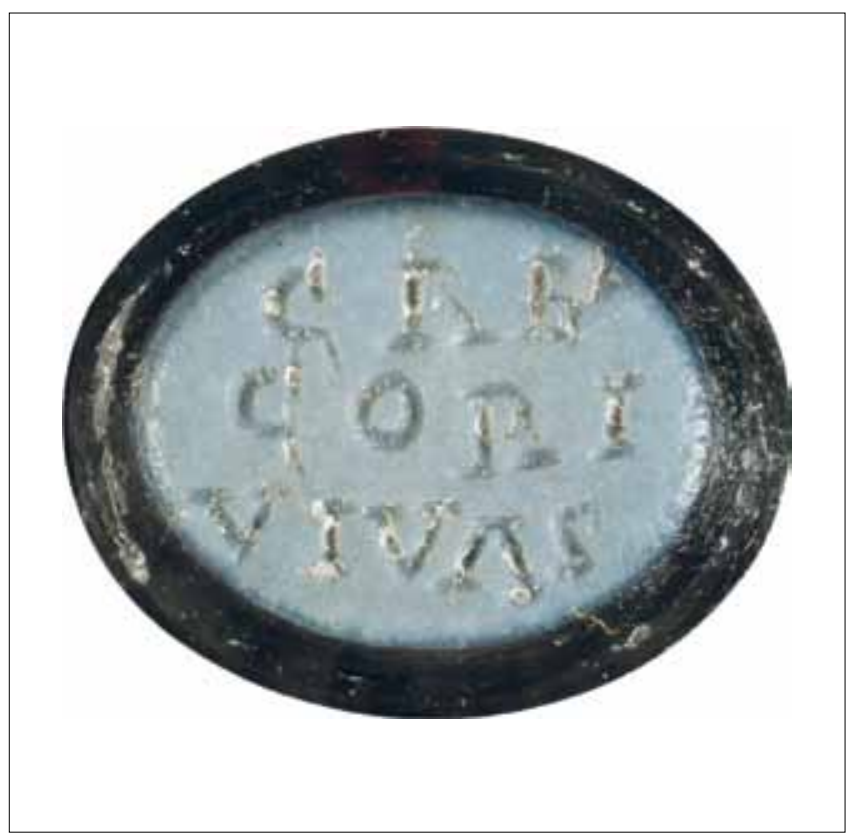

FIGURE 11. Inscription, a nicolo, inv. no. A-16097 (photo by I. Krajcar).

the Andetrian nicolo with the inscription should be dated to the $4^{\text {th }}$ century $A D$, a date that is furthermore confirmed with the find of the $4^{\text {th }}$-century coin of Emperor Gratian. ${ }^{68}$

68 The Christian meaning of the inscription is derived from the instruction given by Christ (Mk 1438 ; Mt 26: 38, 41) to his disciples, asking them to keep vigil (Vollenweider 1979, 261-263, cat. no. 272 bis, n. 15; Kaić 2017, 483, n. 18).

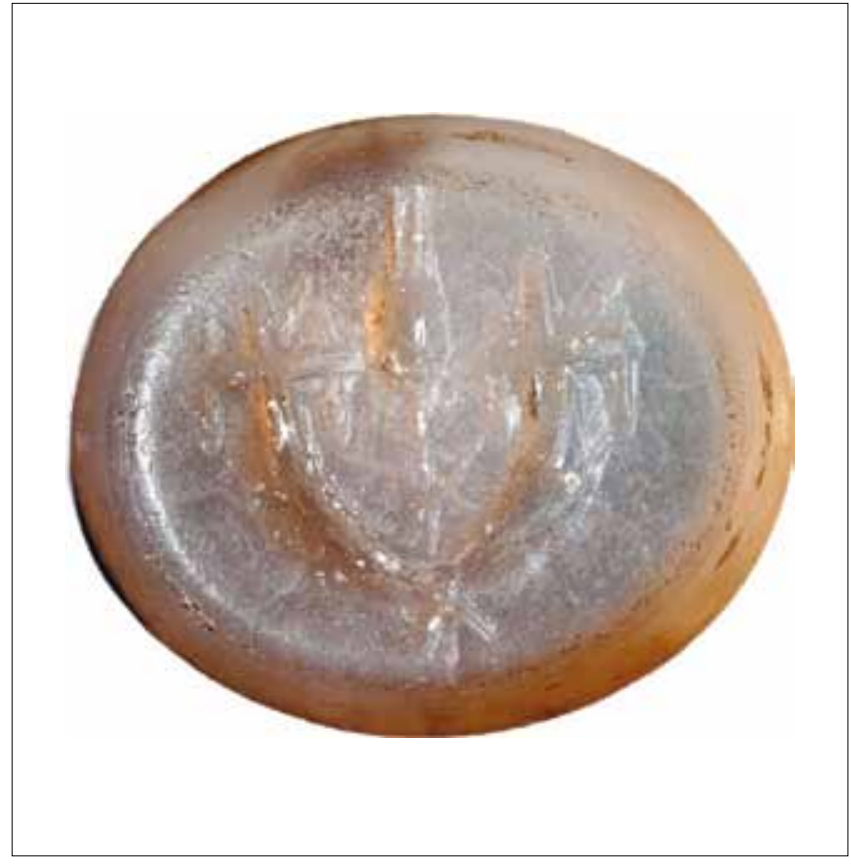

FIGURE 10. A combination of symbols, a chalcedony, inv. no. A-16317 (photo by I. Krajcar).

\section{Conclusion}

The engraved gems from Gornji Muć display various stylistic trends which occur in the Roman glyptics of the Imperial period, dating them to the $1^{\text {st }}$ and $2^{\text {nd }}$ centuries AD. Only one intaglio belongs to the period of Late Antiquity (Fig. 11), bearing an Early Christian inscription.

Among the various motifs which appear on the Andetrian engraved gems, we cannot perceive any peculiarities or differences in relation to standard Roman glyptic production.

Taking into consideration the military nature of the site, it is not surprising that we find intaglios showing Jupiter (Fig. 1), Minerva (Fig. 2) and eagles between legionary signa (Figs 8-9), all subjects closely related to the Roman army. A carnelian depicting the hero Perseus (Fig. 4) also fits well into that frame. Other intaglios bear witness to religious worship (Figs 3, 6), point to the lifestyle of their owner (Fig. 7) or allude to fertility and prosperity (Fig. 10). The unfinished engraving of the chrome chalcedony (Fig. 5) suggests it was perhaps manufactured in a local workshop.

For the present time, most of our knowledge of Roman Andetrium has been acquired through analysis of the preserved Roman finds. This group of engraved gems from Gornji Muć is thus important in our understanding of the Roman presence, both military and civilian, in the Muć Valley area. 


\section{ABBREVIATIONS}

AGDS I/2 - E. Brandt, E. Schmidt, Antike Gemmen in deutschen Sammlungen I, Staatliche Münzsammlung München 2, Italische Gemmen etruskisch bis römisch-republikanisch, Italische Glaspasten vorkaiserzeitlich, Prestel Verlag, 1970.

AGNürnberg - C. Weiss, Antike Gemmen in deutschen Sammlungen 5, Die antiken Gemmen in Sammlung Friedrich Julius Rudolf Bergau im Germanischen Nationalmuseum, Germanisches Nationalmuseum Nürnberg, 1996.

AGWien 1 - E. Zwierlein-Diehl, Die antiken Gemmen des Kunsthistorischen Museums in Wien 1, Die Gemmen von der minoischen Zeit bis zur frühen römischen Kaiserzeit, Prestel Verlag, 1973.
AGWien 3 - E. Zwierlein-Diehl, Die antiken Gemmen des Kunsthistorischen Museums in Wien 3, Die Gemmen der späteren römischen Kaiserzeit 2, Masken, Masken - Kombinationen, Phantasie- und Märchentiere, Gemmen mit Inschriften, Christliche Gemme, Magische Gemmen, Sasanidische Siegel, Rundplastik aus Edelstein und verwandten Material, Kameen, Prestel Verlag, 1991.

CIL 3 - Corpus inscriptionum Latinarum 3. Inscriptiones Asiae, provinciarum Graecarum, Illyrici, Georg Reimer, 1902.

\section{BIBLIOGRAPHY}

Aubry 2011 - S. Aubry, Inscriptions on Portrait Gems and Discs in Late Antiquity ( $3^{\text {rd }}-6^{\text {th }}$ centuries AD), in Entwistle, C., Adams, N. (eds.), Gems of Heaven: Recent Research on Engraved Gemstones in Late Antiquity, C. AD $200-600$, The British Museum, 2011, 239-247

Bekić 2011 - L. Bekić, Andetrij, rimsko vojno uporište. Topografske odrednice, in Librenjak, A., Tončinić, D. (eds.), Arheološka istraživanja u Cetinskoj krajini: znanstveni skup, Sinj, 10. - 13. listopada 2006., Izdanja Hrvatskog arheološkog društva 27, 2011, 315-325.

Cesarik 2018 - N. Cesarik, River Crossings and Roman Auxiliary Forts: The Evidence from the River Cetina, Collegium antropologicum 42/1, 2018, 53-63.

Dembski 2005 - G. Dembski, Die antiken Gemmen und Kameen aus Carnuntum, Phoibos Verlag, 2005

Henig 1970 - M. Henig, The Veneration of Heroes in the Roman Army: The Evidence of Engraved Gemstones, Britannia 1, 1970, 249-265.

Henig 1990 - M. Henig, The Content Family Collection of Ancient Cameos, Ashmolean Museum, Derek Content, 1990.

Henig 2007 - M. Henig, A Corpus of Roman Engraved Gemstones from British Sites ( $3^{\text {rd }}$ edition), BAR British Series $8,2007^{3}$.

Henig, Whiting 1987 - M. Henig, M. Whiting, Engraved Gems from Gadara in Jordan: the Sa'd Collection of Intaglios and Cameos, Oxford University Committee for Archaeology, 1987.

Hoey Middleton 1991 - S. Hoey Middleton, Engraved Gems from Dalmatia: from the Collections of Sir John Gardner Wilkinson and Sir Arthur Evans in Harrow School, at Oxford and elsewhere, Oxford University Committee for Archaeology, 1991

Kaić 2013 - I. Kaić, Rimski svijet u malome. Geme kao svjedočanstva svakodnevnog života, unpublished PhD thesis, Faculty of Humanities and Social Studies, University of Zagreb, 2013

Kaić 2015 - I. Kaić, Roman Gems from the Limes in the Collection of the Archaeological Museum in Zagreb (Croatia), in Vagalinski, L., Sharankov, N. (eds.), Limes XXII: Proceedings of the $22^{\text {nd }}$ International Congress of Roman Frontier Studies Ruse, Bulgaria, September 2012, Bulletin of the National Archaeological Institute 42, 2015, 805-808.

Kaić 2017 - I. Kaić, Roman intaglios with inscriptions from the Archaeological Museum in Zagreb, in Demicheli, D. (ed.), Illyrica antiqua 2 - in honorem Duje Rendić Miočević, Proceedings of the international conference, Šibenik, $12^{\text {th }}$ $15^{\text {th }}$ September 2013, Department for Archaeology, Faculty of Humanities and Social Sciences, University of Zagreb, 2017, 479-486.

Kaić 2020 - I. Kaić, Engraved gems from Tilurium in the Zagreb Archaeological Museum, in Tončinić, D. Kaić, I., Matijević, V., Vukov, M. (eds.), Studia honoraria archaeologica: zbornik radova u prigodi 65 . rođendana prof. dr. sc. Mirjane Sanader, Archaeological Institute, Faculty of Humanities and Social Sciences, University of Zagreb, FF Press, 2020, 183-192.
Kaić 2021 - I. Kaić, Tracing foreign identities on Roman engraved gems. Several Examples from the Archaeological Museum in Zagreb, in Lipps, J. (ed.), People Abroad. Proceedings of the XVI. International Colloquium on Roman Provincial Art, April $9^{\text {th }}-13^{\text {th }} 2019$, Tübinger Archäologische Forschungen 31 , Verlag Marie Leidorf, 2021, 287-295

Larese, Nardelli (eds.) 1991 - A. Larese, B. Nardelli (eds.), Tesori nazionali della Croazia-Capolavori dei musei di Zagabria-Arheološki muzej, Centro Affari e Promozioni Arezzo Nuova Grafica Fiorentina, 1991.

Luetić 2001 - T. Luetić, Darovi i davatelji Arheološkom odjelu Narodnog zemaljskog muzeja u Zagrebu od 1868. do 1875. godine, Vjesnik Arheološkog muzeja u Zagrebu 34, 2001, 217-264.

Ljubić 1879 - Š. Ljubić, Razne viesti, dopisi, Vjesnik Arheološkog muzeja u Zagrebu 1, 1879, 122-128.

Maaskant-Kleibrink 1978 - M. Maaskant-Kleibrink, Catalogue of the Engraved Gems in the Royal Coin Cabinet, The Hague 1-2, The Hague Government Publishing Office, Steiner Verlag, 1978.

Magni 2009 - A. Magni, Le gemme di età classica, in Sena Chiesa, G. (ed.) Gemme dei Civici Musei d'Arte di Verona, Giorgio Bretschneider Editore, 2009, $17-142$.

Maixner 1881a - F. Maixner, Intagliji u zemaljskom muzeju zagrebačkom (I), Viestnik Hrvatskoga arkeologičkoga družtva 3, 1881, 75-84.

Maixner 1881b - F. Maixner, Intagliji u zemaljskom muzeju zagrebačkom (II), Viestnik Hrvatskoga arkeologičkoga družtva 3, 1881, 108-121.

Mandrioli Bizzarri 1987 - A. R. Mandrioli Bizzarri, La Collezione di gemme de Museo Civico Archeologico di Bologna, Comune di Bologna, Grafis Edizioni, 1987.

Matijević 2011 - I. Matijević, Natpisi Prve kohorte Belgâ iz Salone, Vjesnik za arheologiju i povijest dalmatinsku 104, 2011, 181-207.

Mirnik 2010 - I. Mirnik, Dopisivanje don Mije Jerka Granića iz Muća Gornjeg s don Šimom Ljubićem u Zagrebu, in Šeparović, T. (ed.), Zbornik Stjepan Gunjača i hrvatska povijesno-arheološka baština 1, Muzej hrvatskih arheoloških spomenika-Split, 2010, 63-92.

Nardelli 2005 - B. Nardelli, Religious testimonies found on Roman Gems from Dalmatia kept in the Archaeological Museum in Venice, in Sanader, M., Rendić-Miočević, A. (eds.), Religija i mit kao poticaj rimskoj provincijalnoj plastici: Akti VIII međunarodnog kolokvija o problemima rimskog provincijalnog stvaralaštva / Religion und Mythos als Anregung für die provinzialrömische Plastik: Akten des VIII Internationalen Kolloquiums über Probleme des provinzialrömischen Kunstschaffens, Golden marketing-Tehnička knjiga, 2005 $237-242$

Nardelli 2007 - B. Nardelli, La rappresentazione della società romana nelle gemme rinvenute in Dalmazia, in Walde, E.,Kainrath, B. (eds), Die Selbstdarstellung der römischen Gesellschaft in den Provinzen im Spiegel der Stein- 
denkmäler: Akten des IX. Internationalen Kolloquiums über Probleme des provinzialrömischen Kunstschaffens, Innsbruck University Press, 2007, 265-273.

Nardelli 2011 - B. Nardelli, Gemme antiche dalla Dalmazia: intagli e cammei da Tilurium, self-published, 2011.

Nardelli 2011 b - B. Nardelli, II modello della capitale e la produzione glittica in Dalmatia, in Nogales, T., Rodà, I. (eds.), Roma i las provincias: modelo y difusión 1, L’Erma di Bretschneider, 2011, 297-303.

Nardelli 2012 - B. Nardelli, Late Roman Gems from Tilurium in Croatia, in Entwistle, C. Adams, N. (eds), Gems of Heaven: Recent Research on Engraved Gemstones in Late Antiquity, C. AD 200 - 600, The British Museum, 2012, 130134 .

Nemeth-Ehrlich 1993a - D. Nemeth-Ehrlich, Catalogue entries no. 213-214 216-219, 226, 228-229, 235-246, in Rendić-Miočević, A. (ed.), Arheološki muzej u Zagrebu: izbor iz fundusa, Arheološki muzej u Zagrebu, 1993, 160-164, 166168.

Nemeth-Ehrlich 1993b - D. Nemeth-Ehrlich, Catalogue entries no. 213-214 216-219, 226, 228-229, 235-246, in Rendić-Miočević, A. (ed.), Arte e Cultura in Croazia-dalle collezioni del Museo archeologico e del Museo d'arte ed arti decorative di Zagabria, Museo di antichità Torino, 1993, 160-164, 166-168.

Platz-Horster 2010 - G. Platz-Horster, "Kleine Praser" and Chromium-bearing Chalcedonies. About a Small Group of Engraved Gems, Pallas 83, 2010, 179-202.
Rendić-Miočević 1987 - A. Rendić-Miočević, Catalogue entries no. 37, 77, 128, 131, 158, 161, in Jevtović, J. (ed.), Antčki portret u Jugoslaviji / Classical portraits in Yugoslavia, Narodni muzej Beograd, Muzeji Makedonije, Arheološki muzej u Zagrebu, Arheološki muzej u Splitu, Narodni muzej u Ljubljani, 1987, 131, 141, 162, 189-190, 204-205.

Sena Chiesa 1966 - G. Sena Chiesa, Gemme del Museo Nazionale di Aquileia, Associazione nazionale per Aquileia, 1966.

Šeper 1942 - M. Šeper, Antikne geme - amuleti nazvane po gnostičkim gemama, Vjesnik Arheološkog muzeja u Zagrebu 22-23, 1942, 5-54.

Tončinić, Tabak, Librenjak 2011 - D. Tončinić, A. Tabak, A. Librenjak, Rimski vojni pečati u Cetinskoj krajini, in Librenjak, A., Tončinić, D. (eds.), Arheološka istraživanja u Cetinskoj krajini: znanstveni skup, Sinj, 10. - 13. listopada 2006., Izdanja Hrvatskog arheološkog društva 27, 2011, 361-379.

Vollenweider 1979 - M. L. Vollenweider, Catalogue raisonné des sceaux, cylindres, intailles et camées 2: Les portraits, les masques de théatre, les symboles politiques. Une contribution à l'histoire des civilisations hellénistique et ro maine, Musée d'art et d'histoire, P. von Zabern, 1979.

Zwierlein-Diehl 2007 - E. Zwierlein-Diehl, Antike Gemmen und ihr Nachleben, Walter de Gruyter, 2007. 